\title{
Development of Pathotype-Specific SCAR Markers for Detection of Verticillium albo-atrum Isolates from Hop
}

Sebastjan Radišek, Plant Protection Department, Slovenian Institute of Hop Research and Brewing, Cesta Žalskega tabora 2, SI-3310 Žalec, Slovenia; and Jernej Jakše and Branka Javornik, Centre for Plant Biotechnology and Breeding, Agronomy Department, Biotechnical Faculty, Jamnikarjeva 101, Ljubljana 1000, Slovenia

\begin{abstract}
Radišek, S., Jakše, J., and Javornik, B. 2004. Development of pathotype-specific SCAR markers for detection of Verticillium albo-atrum isolates from hop. Plant Dis. 88:1115-1122.

Rapid polymerase chain reaction (PCR) assays were developed for the identification and detection of Verticillium albo-atrum hop pathotypes PG1 and PG2 from Slovenia. Of 17 pathotypelinked amplified fragment length polymorphism (AFLP) markers, 11 were cloned successfully and sequenced. To convert polymorphic AFLP markers into pathotype-specific sequencecharacterized amplified region (SCAR) markers, 22 PG2- and 10 PG1-specific primer pairs were designed from 16 sequences. When primer specificity was tested on a wide range of Verticillium isolates, 10 PG2- and 6 PG1-specific primer pairs retained amplification specificity for $V$. alboatrum Slovene hop isolates, but also amplified sequences in $V$. albo-atrum and $V$. dahliae hop isolates from different hop production areas in Europe, as well as in some isolates from other hosts. Primer combinations obtained from the AFLP-9-1 marker were specific only for V. alboatrum PG2 isolates. The highly specific primers were used in multiplex PCR and a nested PCR to detect the V. albo-atrum PG2 pathotype in xylem tissue of hop plants. These new SCAR markers provide a valuable tool for rapid identification of V. albo-atrum PG1 and PG2 hop pathotypes.
\end{abstract}

Additional keywords: hop wilt, Humulus lupulus

Verticillium albo-atrum Reinke \& Berthier and $V$. dahliae Kleb. are important plant-pathogenic fungi causing vascular wilts in many crop species (9). In Europe, these two soilborne fungi have caused considerable economic damage on hop (Humulus lupulus L.), with V. albo-atrum being the principal pathogen in most hopgrowing areas (21). Hop is a perennial plant that needs an extensive support system for cultivation; therefore, contamination of hop gardens with Verticillium spp. is a major limiting factor in hop production. Due to the lack of effective chemical control, crop rotation, planting resistant or tolerant cultivars, and carrying out phytosanitary measures are the only successful means of preventing Verticillium wilt.

Verticillium wilt on hops has appeared in fluctuating (mild) or progressive (lethal) forms, depending on the pathogen virulence, the sensitivity of cultivars, and ecological factors $(13,26,29)$. The main differ-

Corresponding author: B. Javornik

E-mail: branka.javornik@uni-il.si

This study was funded by the Ministry of Education, Science and Sport, contracts no. S4-486019/20162 and PO-0513-0481.

Accepted for publication 2 June 2004.

Publication no. D-2004-0726-01R

(C) 2004 The American Phytopathological Society ence between the forms is that the lethal one causes hop to wither, whereas plants continue to grow with the mild form. In England, three types of lethal $V$. alboatrum isolates (PV1, PV2, and PV3) have been reported, which can be distinguished on the basis of pathogenicity tests on different sets of hop cultivars (27).

Slovenia has three main hop-production areas: Savinja Valley $(1,000 \mathrm{ha})$, the Koroska area (400 ha), and the Podravje area (300 ha). The first record of Verticillium wilt in Slovenia was in 1974, when the mild form was detected as a cause of infection by $V$. albo-atrum and $V$. dahliae (8). Hop wilt appeared only sporadically in some hop gardens until 1997, when an outbreak of the lethal form was reported in the western part of the Savinja valley and $V$. albo-atrum was identified as the casual agent. Over the next 6 years, new outbreaks of the lethal form were detected in a radius of $7 \mathrm{~km}$ from the first outbreak and, to date, more than 180 ha of hop gardens have been affected (Annual Report for 2003: Monitoring Survey of Hop Wilt [Verticillium albo-atrum and $V$. dahliae] in 2003. MAFF; Republic of Slovenia, unpublished). On the basis of pathogenicity tests and molecular analysis, V. albo-atrum hop isolates from Slovenia have been classified as PG1 (mild) and PG2 (lethal) pathotypes (21). The spread of the PG2 pathotype is a serious threat to Slovene hop production, in view of the close prox- imity of hop gardens to each other in all production areas and the prevalence of susceptible hop cultivars.

The identification and rapid detection of pathotypes is very important for adequate disease management and for resistance breeding. V. albo-atrum hop isolates have been best characterized by pathogenicity tests $(5,27)$. These bioassays are laborious and time-consuming; therefore, the development of a more rapid method is required. In the last decade, various molecular genetic techniques have been applied for the characterization and detection of Verticillium spp. Differences in internal transcribed spacer (ITS) regions ITS1 and ITS2 of nuclear rDNA enable the development of polymerase chain reaction (PCR) primers specific for the identification of $V$. albo-atrum, V. dahliae, and V. tricorpus $(17,19,24)$. Specific primers have been used for the detection and quantification of Verticillium biomass in different host plants and in soil samples $(11,12,16$, 18,23). However, specific primers for the detection of $V$. albo-atrum hop isolates have not yet been developed. In our study on the molecular variability of $V$. alboatrum isolates, 17 amplified fragment length polymorphism (AFLP) markers linked to the virulence of hop isolates from Slovenia were identified (22), providing potential markers to be converted into specific, single-locus diagnostic markers (20).

Our objective in this study was to develop specific sequence-characterized amplified region (SCAR) markers for the determination of $V$. albo-atrum PG1 and PG2 hop pathotypes. We also report here on the use of specific SCAR primer pairs in multiplex PCR for distinguishing the two pathotypes, and in nested PCR assays for the detection of these pathotypes in hop plants.

\section{MATERIALS AND METHODS}

Fungal isolates. In all, 92 Verticillium isolates were obtained from different geographical locations in Europe and North America (Table 1). Of the V. albo-atrum isolates, 55 were from infected hop plants from important hop production areas in Europe (34 from Slovenia, 15 from the United Kingdom, 5 from Germany, and 1 from Poland). The other isolates represented different host plants, geographic locations, or Verticillium spp. (dahliae, 
Table 1. Fungal isolates used in this study and the amplification specificity of sequence-characterized amplified region (SCAR) markers ${ }^{\mathrm{a}}$

\begin{tabular}{|c|c|c|c|c|c|c|c|c|c|c|c|c|c|c|c|c|c|c|}
\hline \multirow[b]{2}{*}{ Species } & \multirow{2}{*}{$\begin{array}{c}\text { Isolate } \\
\text { designation }\end{array}$} & \multirow{2}{*}{$\begin{array}{c}\text { Host or } \\
\text { substrate }^{b}\end{array}$} & \multirow[b]{2}{*}{$\mathbf{P G}^{\mathbf{c}}$} & \multirow{2}{*}{$\begin{array}{l}\text { Geographical } \\
\text { origin }\end{array}$} & \multirow[b]{2}{*}{ Source $^{d}$} & \multicolumn{2}{|c|}{ S-1 } & \multicolumn{2}{|c|}{ S-2 } & S-5-1 & S-9. & & S-9- & & S-10-1 & S-10-2a & $S-11$ & 11 \\
\hline & & & & & & EXT & & EXT & INT I & EXT INT & EXT I & NT & EXT I & INT E & EXT INT & EXT INT & EXT I & INT \\
\hline Verticillium spp. & & & & & & & & & & & & & & & & & & \\
\hline V. albo-atrum & Or00 & Нор & PG2 & Slovenia & IHPS & - & - & - & - & + & + & + & + & + & - & + & + & + \\
\hline V. albo-atrum & Prev & Hop & PG2 & Slovenia & IHPS & - & - & - & - & + & + & + & + & + & - & + & + & + \\
\hline V. albo-atrum & Or99 & Нор & PG2 & Slovenia & IHPS & - & - & - & - & + & + & + & + & + & - & + & + & + \\
\hline V. albo-atrum & Pust & Нор & PG2 & Slovenia & IHPS & - & - & - & - & + & + & + & + & + & - & + & + & + \\
\hline V. albo-atrum & Vran & Нор & PG2 & Slovenia & IHPS & - & - & - & - & + & + & + & + & + & - & + & + & + \\
\hline V. albo-atrum & $\mathrm{Laz}$ & Нор & Lethal (n.t.) $)^{\mathrm{e}}$ & Slovenia & IHPS & - & - & - & - & + & + & + & + & + & - & + & + & + \\
\hline V. albo-atrum & $\operatorname{Tr} 98$ & Hop & PG2 & Slovenia & IHPS & - & - & - & - & + & + & + & + & + & - & + & + & + \\
\hline V. albo-atrum & Roz & Нор & PG2 & Slovenia & IHPS & - & - & - & - & + & + & + & + & + & - & + & + & + \\
\hline V. albo-atrum & $\mathrm{Ciz}$ & Hop & PG2 & Slovenia & IHPS & - & - & - & - & + & + & + & + & + & - & + & + & + \\
\hline V. albo-atrum & Ranc & Нор & PG2 & Slovenia & IHPS & - & - & - & - & + & + & + & + & + & - & + & + & + \\
\hline V. albo-atrum & Pov & Hop & PG2 & Slovenia & IHPS & - & - & - & - & + & + & + & + & + & - & + & + & + \\
\hline V. albo-atrum & $\operatorname{Tr} 99$ & Нор & PG2 & Slovenia & IHPS & - & - & - & - & + & + & + & + & + & - & + & + & + \\
\hline V. albo-atrum & Jer & Нор & PG2 & Slovenia & IHPS & - & - & - & - & + & + & + & + & + & - & + & + & + \\
\hline V. albo-atrum & Rot & Hop & PG2 & Slovenia & IHPS & - & - & - & - & + & + & + & + & + & - & + & + & + \\
\hline V. albo-atrum & $\mathrm{T} 2$ & Нор & PG2 & Slovenia & IHPS & - & - & - & - & + & + & + & + & + & - & + & + & + \\
\hline V. albo-atrum & T6 & Hop & Lethal (n.t.) ${ }^{\mathrm{e}}$ & Slovenia & IHPS & - & - & - & - & + & + & + & + & + & - & + & + & + \\
\hline V. albo-atrum & Vran01 & Hop & PG2 & Slovenia & IHPS & - & - & - & - & + & + & + & + & + & - & + & + & + \\
\hline V. albo-atrum & Led & Hop & PG2 & Slovenia & IHPS & - & - & - & - & + & + & + & + & + & - & + & + & + \\
\hline V. albo-atrum & Pov02 & Hop & Lethal (n.t.) ${ }^{\mathrm{e}}$ & Slovenia & IHPS & - & - & - & - & + & + & + & + & + & - & + & + & + \\
\hline V. albo-atrum & Pec & Нор & Lethal (n.t.) ${ }^{\mathrm{e}}$ & Slovenia & IHPS & - & - & - & - & + & + & + & + & + & - & + & + & + \\
\hline V. albo-atrum & Rov & Hop & PG2 & Slovenia & IHPS & - & - & - & - & + & + & + & + & + & - & + & + & + \\
\hline V. albo-atrum & Roj & Нор & Lethal (n.t.) $)^{\mathrm{e}}$ & Slovenia & IHPS & - & - & - & - & + & + & + & + & + & - & + & + & + \\
\hline V. albo-atrum & Nat & Hop & PG2 & Slovenia & IHPS & - & - & - & - & + & + & + & + & + & - & + & + & + \\
\hline V. albo-atrum & Slan & Hop & Lethal (n.t. $)^{\mathrm{e}}$ & Slovenia & IHPS & - & - & - & - & + & + & + & + & + & - & + & + & + \\
\hline V. albo-atrum & Drc & Нор & PG2 & Slovenia & IHPS & - & - & - & - & + & + & + & + & + & - & + & + & + \\
\hline V. albo-atrum & Urs & Hop & Lethal (n.t. $)^{\mathrm{e}}$ & Slovenia & IHPS & - & - & - & - & + & + & + & + & + & - & + & + & + \\
\hline V. albo-atrum & Jel & Нор & PG2 & Slovenia & IHPS & - & - & - & - & + & + & + & + & + & - & + & + & + \\
\hline V. albo-atrum & Ocer & Hop & PG1 & Slovenia & IHPS & + & + & - & - & - & - & - & - & - & - & - & - & - \\
\hline V. albo-atrum & Kres99 & Hop & PG1 & Slovenia & IHPS & + & + & + & + & - & - & - & - & - & + & - & - & - \\
\hline V. albo-atrum & CasA & Hop & PG1 & Slovenia & IHPS & + & + & + & + & - & - & - & - & - & + & - & - & - \\
\hline V. albo-atrum & Zup & Нор & PG1 & Slovenia & IHPS & + & + & + & + & - & - & - & - & - & + & - & - & - \\
\hline V. albo-atrum & $\operatorname{Rec}$ & Нор & PG1 & Slovenia & IHPS & + & + & + & + & - & - & - & - & - & + & - & - & - \\
\hline V. albo-atrum & Mo3 & Hop & PG1 & Slovenia & IHPS & + & + & + & + & - & - & - & - & - & + & - & - & - \\
\hline V. albo-atrum & KresCer & Нор & PG1 & Slovenia & IHPS & + & + & + & + & - & - & - & - & - & + & - & - & - \\
\hline V. albo-atrum & 11041 & Hop & n.t. & Great Britain & 1 & - & - & - & - & + & - & - & + & - & - & + & - & - \\
\hline V. albo-atrum & 11047 & Нор & n.t. & Great Britain & 1 & - & - & - & - & + & - & - & + & - & - & + & - & - \\
\hline V. albo-atrum & 11052 & Hор & $\mathrm{n}$. & Great Britain & 1 & - & - & - & - & + & - & - & + & - & - & + & - & - \\
\hline V. albo-atrum & 11055 & Hop & n.t. & Great Britain & 1 & - & - & - & - & + & - & - & + & - & - & + & - & - \\
\hline V. albo-atrum & 11056 & Нор & n.t. & Great Britain & 1 & - & - & - & - & + & - & - & + & - & - & + & - & - \\
\hline V. albo-atrum & 11097 & Hop & n.t. & Great Britain & 1 & - & - & + & - & + & - & - & + & - & - & + & - & - \\
\hline V. albo-atrum & 298092 & Нор & Fluctuating & Great Britain & CABI & - & - & - & - & - & - & - & - & - & - & - & - & - \\
\hline V. albo-atrum & 298095 & Hop & Fluctuating & Great Britain & CABI & - & - & - & - & - & - & - & - & - & - & - & - & - \\
\hline V. albo-atrum & 298099 & Hop & Lethal & Great Britain & CABI & - & - & - & - & + & - & - & + & - & - & + & - & - \\
\hline V. albo-atrum & 298100 & Hop & Lethal & Great Britain & CABI & - & - & - & - & + & - & - & + & - & - & + & - & - \\
\hline V. albo-atrum & 298101 & Нор & Lethal; supvir & Great Britain & CABI & - & - & - & - & + & - & - & + & - & - & + & - & - \\
\hline V. albo-atrum & 298102 & Нор & Lethal; supvir & Great Britain & CABI & - & - & - & - & + & - & - & + & - & - & + & - & - \\
\hline V. albo-atrum & 1974 & Hop & Lethal & Great Britain & 2 & - & - & - & - & + & - & - & + & - & - & + & - & - \\
\hline V. albo-atrum & 1985 & Hop & Lethal & Great Britain & 2 & - & - & - & - & + & - & - & + & - & - & + & - & - \\
\hline V. albo-atrum & 1953 & Hop & Fluctuating & Great Britain & 2 & - & - & + & + & - & - & - & - & - & - & - & - & - \\
\hline V. albo-atrum & Sol & Hop & n.t. & Poland & 3 & + & + & + & + & - & - & - & - & - & + & - & - & - \\
\hline V. albo-atrum & 1140 & Нор & n.t. & Germany & 4 & - & - & - & - & - & - & - & - & - & - & - & - & - \\
\hline V. albo-atrum & $16 / 00$ & Нор & n.t. & Germany & 4 & - & - & - & - & - & - & - & - & - & - & - & - & - \\
\hline V. albo-atrum & $14 / 93$ & Hop & n.t. & Germany & 4 & - & - & - & - & - & - & - & - & - & - & - & - & - \\
\hline V. albo-atrum & $6 / 99$ & Hop & n.t. & Germany & 4 & + & + & + & + & - & - & - & - & - & + & - & - & - \\
\hline V. albo-atrum & $15 / 98$ & Нор & n.t. & Germany & 4 & + & + & + & + & - & - & - & - & - & + & - & - & - \\
\hline V. albo-atrum & 11 & Alfalfa & n.t. & Canada & 5 & - & - & - & - & + & - & - & + & - & - & - & + & + \\
\hline V. albo-atrum & 41 & Alfalfa & n.t. & Canada & 5 & - & - & - & - & + & - & - & + & - & - & - & + & + \\
\hline V. albo-atrum & 107 & Alfalfa & n.t. & United States & 5 & - & - & - & - & + & - & - & + & - & - & - & + & + \\
\hline V. albo-atrum & 140 & Alfalfa & n.t. & United States & 5 & - & - & - & - & + & - & - & + & - & - & $-\quad-$ & + & + \\
\hline & & & & & & & & & & & & & & & & tinued on & & \\
\hline
\end{tabular}

a EXT and INT: SCAR markers generated from the external and internal part, respectively, of the AFLP marker; SCAR marker amplified (+) or not amplified (-).

${ }^{b}$ Alfalfa (Medicago sativa), Cave cricket (C. cricket; Troglophilus neglectus), Chrysanthemum (Chrys; Chrysanthemum sp.), Cucumber (Cucumis sativus), Fat-hen (Chenopodium album), Green pepper (G. pepper; Capsicum annuит), Hop (Humulus lupulus), Japanese maple (J. maple; Acer palmatum), Linden (Tilia sp.), Petunia (Petunia hybrida), Potato (Solanum tuberosum), Southern catalpa (S. catalpa; Catalpa bignonioides), Tomato (Lycopersicon esculentum), and ... = unknown.

${ }^{\mathrm{c}} \mathrm{PG}=$ pathogenicity group; Supvir $=$ supervirulent, $\mathrm{Vir}=$ virulent, $\mathrm{Avr}=$ avirulent, and $\mathrm{R}$ tom $=$ on resistant tomato.

d IHPS = Slovenian Institute for Hop Research and Brewing, Žalec, Slovenia; CABI = CABI Bioscience, Genetic Resources Collection, Bakeham Lane, Surrey, UK; 1 = Dr. G. Down, Disease Management, Horticulture Research International, West Malling, UK; 2 = Dr. D. J. Barbara, Horticulture Research International, Wellesbourne, Warwick, UK; 3 $=$ Dr. E. Solarska, Institute of Soil Science and Plant Cultivation, Pulawy, Poland; 4 = Dr. E. Seigner, Bayer Landesanstalt fur Bodenkultur und Pflanzenbau, Freising, Germany; 5 = Dr. J. Robb, University of Guelph, Molecular Biology and Genetics, Canada; 6 = Dr. R. Cooper, University of Bath, Department of Biology and Biochemistry, Bath, UK; $7=$ Dr. J. K. Goud, Biological Farming Systems, Wageningen, Holland; MZKI = Microbiological Culture Collection of the National Institute of Chemistry, Ljubljana, Slovenia.

${ }^{\mathrm{e}}$ Isolates from plants with lethal form of Verticillium wilt, not tested (n.t.) by pathogenicity test. 
tricorpus, lecani, luteoalbum, and theobromae). In addition, some common saprotrophic soil fungi also were included (Table 1).

Of the 34 Slovene hop isolates, 27 had been characterized as PG1 or PG2 pathotypes by pathogenicity tests based on the disease reaction of four hop cultivars (22). The remaining seven hop isolates were considered to be lethal in view of the symptoms on the plants from which they were isolated. Pathogenicity characterization of other isolates (Table 1) was specified by the supplier.

All isolates used in this study were maintained in the culture collection of the Slovenian Institute for Hop Research and Brewing, Slovenia, as monospore cultures on potato dextrose agar (PDA; Fluka, Buchs, Switzerland) at $4^{\circ} \mathrm{C}$, or stored as cultures in general fungal medium (31) in $20 \%$ glycerol at $-80^{\circ} \mathrm{C}$. The species identification of isolates was checked by examining them using light microscopy.

Plant inoculation. V. albo-atrum hop isolates Tr99 (pathotype PG2) and KresCer (pathotype PG1) were used to inoculate 6week-old plants of susceptible hop cvs. Fuggle and Celeia, moderately resistant Wye Challenger, and resistant cv. Wye Target. Five plants of each cultivar grown as a single bine were inoculated by stempuncture inoculation in the basal part of the bine. Control plants were inoculated similarly with sterile distilled water. Inoculum preparation and symptom assessment were carried out according to Radišek et al. (22). For re-isolation, the xylem tissue 10 to $20 \mathrm{~cm}$ above the inoculation point was plated on PDA. The remaining part of the bine was stored at $-80^{\circ} \mathrm{C}$ for DNA extraction. Plants from the above experiment were used for in planta PCR detection of the $V$. albo-atrum PG2 hop pathotype.

Fungal and plant DNA extraction. To obtain mycelia for DNA extraction, cultures were grown by agitation on a rotary shaker $(50 \mathrm{rpm})$ in $50 \mathrm{ml}$ of general fungal medium (31) at room temperature for 5 days in the dark. Fungal genomic DNA was extracted by the sodium dodecyl sulfate (SDS) method of Lee and Taylor (15), with some modifications as described previously (22). Total genomic DNA from infected and noninfected hop plants was extracted by the cetyltrimethylammonium bromide (CTAB) method of Kump and

Table 1. (continued from preceding page)

\begin{tabular}{|c|c|c|c|c|c|c|c|c|c|c|c|c|c|c|c|c|c|c|c|c|c|}
\hline \multirow[b]{2}{*}{ Species } & \multirow{2}{*}{$\begin{array}{c}\text { Isolate } \\
\text { designation }\end{array}$} & \multirow{2}{*}{$\begin{array}{c}\text { Host or } \\
\text { substrate }^{b}\end{array}$} & \multirow[b]{2}{*}{$\mathbf{P G}^{\mathbf{c}}$} & \multirow{2}{*}{$\begin{array}{c}\text { Geographical } \\
\text { origin }\end{array}$} & \multirow{2}{*}{ Source $^{d}$} & \multicolumn{2}{|c|}{ S-1 } & \multicolumn{2}{|c|}{ S-2 } & \multicolumn{2}{|c|}{ S-5-1 } & \multicolumn{2}{|c|}{ S-9-1 } & \multicolumn{2}{|c|}{ S-9-2 } & \multicolumn{2}{|c|}{ S-10-1 } & S-10 & $-2 a$ & S-1 & 11 \\
\hline & & & & & & EXT & INT & EXT & INT & EXT & INT & EXT & INT & EXT & INT I & EXT & INT I & EXT & INT & EXT & INT \\
\hline V. albo-atrum & Luc & Alfalfa & Vir & Great Britain & 6 & - & - & - & - & + & + & - & - & + & - & - & - & - & - & + & + \\
\hline V. albo-atrum & Surf & Petunia & n.t. & Slovenia & IHPS & + & + & + & + & - & - & - & - & - & - & + & + & - & - & - & - \\
\hline V. albo-atrum & Kum & Cucumber & n.t. & Slovenia & IHPS & - & - & - & - & - & - & - & - & - & - & - & - & - & - & - & - \\
\hline V. albo-atrum & 11066 & Potato & n.t. & Great Britain & 1 & - & - & - & - & + & + & - & - & + & - & - & - & + & + & - & - \\
\hline V. albo-atrum & 11077 & Fat-hen & n.t. & Great Britain & 1 & - & - & - & - & + & + & - & - & + & - & - & - & + & + & - & - \\
\hline V. albo-atrum & 11081 & Chrys & n.t. & Great Britain & 1 & - & - & - & - & + & + & - & - & + & - & - & - & + & + & - & - \\
\hline V. albo-atrum & AR01/067 & Tomato & Vir, R tom & Great Britain & 2 & - & - & - & - & + & + & - & - & + & + & - & - & + & + & + & + \\
\hline V. albo-atrum & AR0/140 & & n.t. & Great Britain & 2 & - & - & - & - & + & + & - & - & + & + & - & - & + & + & + & + \\
\hline V. albo-atrum & AR01/JS1 & Tomato & n.t. & Great Britain & 2 & - & - & - & - & + & + & - & - & + & - & + & + & + & + & - & - \\
\hline V. albo-atrum & $\mathrm{T} 179$ & Tomato & Avr, R tom & Great Britain & 2 & - & - & - & - & - & - & - & - & - & - & - & - & - & - & - & - \\
\hline V. albo-atrum & PD2000/4186a & Tomato & n.t. & Holland & 2 & - & - & - & - & - & - & - & - & - & - & - & - & - & - & - & - \\
\hline V. albo-atrum & PD83/53a & Tomato & n.t. & Holland & 2 & - & - & - & - & - & - & - & - & - & - & - & - & - & - & - & - \\
\hline V. dahliae & CasD & Hop & n.t. & Slovenia & IHPS & + & + & - & - & + & + & - & - & - & - & + & + & - & - & - & - \\
\hline V. dahliae & $\mathrm{MoD}$ & Hop & n.t. & Slovenia & IHPS & + & + & - & - & + & + & - & - & - & - & + & + & - & - & - & - \\
\hline V. dahliae & KresD & Hop & n.t. & Slovenia & IHPS & - & - & - & - & + & + & - & - & - & - & - & - & - & - & - & - \\
\hline V. dahliae & 12042 & Hop & n.t. & Great Britain & 1 & - & - & - & - & + & + & - & - & - & - & - & - & - & - & - & - \\
\hline V. dahliae & 12099 & Hop & n.t. & Great Britain & 1 & - & - & - & - & + & + & - & - & - & - & - & - & - & - & - & - \\
\hline V. dahliae & 2390 & Hop & n.t. & Germany & 4 & + & + & - & - & + & + & - & - & - & - & + & + & + & + & + & + \\
\hline V. dahliae & Pap & G. pepper & n.t. & Slovenia & IHPS & + & + & - & - & - & - & - & - & - & - & + & + & - & - & - & - \\
\hline V. dahliae & Pap02 & G. pepper & n.t. & Slovenia & IHPS & + & + & - & - & + & + & - & - & - & - & + & + & - & - & - & - \\
\hline V. dahliae & JKG1 & Potato & n.t. & Holland & 7 & - & - & - & - & - & - & - & - & - & - & - & - & - & - & - & - \\
\hline V. dahliae & JKG8 & Potato & n.t. & Holland & 7 & - & - & - & - & + & + & - & - & - & - & - & - & - & - & - & - \\
\hline V. dahliae & JKG10 & Potato & n.t. & Holland & 7 & + & + & + & + & + & + & - & - & + & - & + & + & + & + & - & - \\
\hline V. dahliae & DJK & Chrys & n.t. & Holland & 7 & - & - & - & - & - & - & - & - & - & - & - & - & - & - & - & - \\
\hline V. dahliae & $\mathrm{MH}$ & Chrys & n.t. & Holland & 7 & - & - & - & - & - & - & - & - & - & - & - & - & - & - & - & - \\
\hline V. dahliae & JKG2 & S. catalpa & n.t. & Holland & 7 & - & - & - & - & - & - & - & - & - & - & - & - & - & - & - & - \\
\hline V. dahliae & JKG7 & S. catalpa & n.t. & Holland & 7 & - & - & - & - & + & + & - & - & - & - & - & - & - & - & - & - \\
\hline V. dahliae & JKG3 & J. maple & n.t. & Holland & 7 & + & + & + & + & + & + & - & - & + & + & + & + & - & - & + & + \\
\hline V. tricorpus & EXF8 & Soil & n.t. & Holland & 7 & - & - & - & - & - & - & - & - & - & - & - & - & - & - & - & - \\
\hline V. tricorpus & JKG20 & Linden & n.t. & Holland & 7 & - & - & - & - & - & - & - & - & - & - & - & - & - & - & - & - \\
\hline V. lecanii & B-560 & C. cricket & n.t. & Slovenia & MZKI & - & - & - & - & - & - & - & - & - & - & - & - & - & - & - & - \\
\hline V. luteoalbum & B-308 & Soil & n.t. & Slovenia & MZKI & - & - & - & - & - & - & - & - & - & - & - & - & - & - & - & - \\
\hline V. theobromae & B-23 & $\ldots$ & n.t. & $\ldots$ & MZKI & - & - & - & - & - & - & - & - & - & - & - & - & - & - & - & - \\
\hline Alternaria & & & & & & & & & & & & & & & & & & & & & \\
\hline radicina & B269 & $\ldots$ & n.t. & France & MZKI & - & - & - & - & - & - & - & - & - & - & - & - & - & - & - & - \\
\hline Armillaria mellea & G56 & $\ldots$ & n.t. & Slovenia & MZKI & - & - & - & - & - & - & - & - & - & - & - & - & - & - & - & - \\
\hline Aspergillus flavus & A168 & $\ldots$ & n.t. & France & MZKI & - & - & - & - & - & - & - & - & - & - & - & - & - & - & - & - \\
\hline Cladosporium & & & & & & & & & & & & & & & & & & & & & \\
\hline oxysporum & B245 & $\ldots$ & n.t. & Slovenia & MZKI & - & - & - & - & - & - & - & - & - & - & - & - & - & - & - & - \\
\hline Fusarium & & & & & & & & & & & & & & & & & & & & & \\
\hline $\begin{array}{l}\text { oxysporum f. sp. } \\
\text { lycopersicum }\end{array}$ & B37 & $\ldots$ & n.t. & $\ldots$ & MZKI & - & - & - & - & - & - & - & - & - & - & - & - & - & - & - & - \\
\hline F. oxysporum & B36 & $\ldots$ & n.t. & $\ldots$ & MZKI & - & - & - & - & - & - & - & - & - & - & - & - & - & - & - & - \\
\hline F. solani & B27 & $\ldots$ & n.t. & $\ldots$ & MZKI & - & - & - & - & - & - & - & - & - & - & - & - & - & - & - & - \\
\hline Monillia sp & $\mathrm{K} 3$ & $\ldots$ & n.t. & $\ldots$ & MZKI & - & - & - & - & - & - & - & - & - & - & - & - & - & - & - & - \\
\hline Penicillium & & & & & & & & & & & & & & & & & & & & & \\
\hline chrysogenum & P90 & $\ldots$ & n.t. & Slovenia & MZKI & - & - & - & - & - & - & - & - & - & - & - & - & - & - & - & - \\
\hline Trichoderma & & & & & & & & & & & & & & & & & & & & & \\
\hline harzianum & B244 & $\ldots$ & n.t. & Slovenia & MZKI & - & - & - & - & - & - & - & - & - & - & - & - & - & - & - & - \\
\hline Trichoderma & & & & & & & & & & & & & & & & & & & & & \\
\hline viridae & B118 & $\ldots$ & n.t. & United States & MZKI & - & - & - & - & - & - & - & - & - & - & - & - & - & - & - & - \\
\hline
\end{tabular}


Javornik (14). For DNA extraction, plant xylem was removed from the bines with a sterile scalpel, finely cut, ground to a coarse powder in the presence of liquid nitrogen, and suspended in extraction buffer (2\% wt/vol CTAB, $1.4 \mathrm{M} \mathrm{NaCl}, 20 \mathrm{mM}$ EDTA, 0.1 M Tris-HCl, $\mathrm{pH} \quad 8.0, \quad 0.2 \% \quad \beta$ mercaptoethanol). Samples were extracted with equal volumes of chloroform:isoamylalcohol (24:1). DNA was precipitated with a $1 / 10$ volume of $3 \mathrm{M}$ Na-acetate $(\mathrm{pH}$ 5.2) and 1 volume of isopropanol, washed in $70 \%$ ethanol, and resuspended in $30 \mu \mathrm{l}$ of Tris-EDTA (TE) buffer (10 mM Tris-HCl, 1 mM EDTA, pH 8.0).

Isolation, cloning, and sequencing of AFLP fragments. Nine AFLP primer combinations generating $V$. albo-atrum hop pathotype-specific fragments in our previous study (22) and two additional AFLP primer combinations (EcoRI-GA/MspI-CG and EcoRI-GT/MspI-CG) also giving pathotype-specific fragments (Table 2) were used to generate corresponding markers by AFLP analysis. These AFLP fragments were excised from the polyacrylamide gels and reamplified in $50 \mu \mathrm{l}$ of reaction mixture using the same primer pairs that identified the polymorphic AFLP fragment. The amplification products were electrophoresed on $1.2 \%$ agarose gel in $1 \times$ Tris-acetate EDTA buffer. Following visualization under UV light, the fragments were excised from the gel and purified using a silica suspension (2). The purified AFLP fragments were blunt-end ligated into bacterial plasmid PCR-Script Amp SK $(+)$, transformed into Epicurian Coli XL10-Gold Ultracompetent Cells, and selected using the blue/white method according to the manufacturer's (Stratagene, La Jolla, CA) instructions. After cloning, 20 positive colonies from each transformation were selected and each colony was cultured overnight in Luria-Bertani liquid medium containing ampicillin at 100

Table 2. Primer combinations of EcoRI and MspI used to generate Verticillium albo-atrum hop-pathotype specific amplified fragment length polymorphism (AFLP) markers

\begin{tabular}{|c|c|c|}
\hline Primer combination & AFLP marker designation & Specific for ${ }^{\mathrm{a}}$ \\
\hline EcoRI-GA/MspI-AT & AFLP $-1^{\mathrm{b}}$ & PG1 \\
\hline EcoRI-GA/MspI-TA & AFLP- $2^{b}$ & PG1 \\
\hline$E c o$ RI-GA/MspI-AG & AFLP- $3^{b}$ & PG1 \\
\hline EcoRI-GA/MspI-CG & AFLP-4b & PG2 \\
\hline \multirow[t]{2}{*}{ EcoRI-GA/MspI-GT } & AFLP-5-1 $1^{\mathrm{b}}$ & PG2 \\
\hline & AFLP-5-2 $2^{b}$ & PG2 \\
\hline \multirow[t]{2}{*}{ EcoRI-GT/MspI-GA } & AFLP-6-1 & PG1 \\
\hline & AFLP-6-2 & PG2 \\
\hline \multirow[t]{2}{*}{ EcoRI-GT/MspI-CG } & AFLP-7-1 & PG2 \\
\hline & AFLP-7-2 & PG2 \\
\hline \multirow[t]{2}{*}{ EcoRI-AC/MspI-TC } & AFLP-8-1 & PG2 \\
\hline & AFLP-8-2 & PG1 \\
\hline \multirow[t]{2}{*}{ EcoRI-AC/MspI-TA } & AFLP-9-1 ${ }^{\mathrm{b}}$ & PG2 \\
\hline & AFLP-9-2 ${ }^{\mathrm{b}}$ & PG2 \\
\hline \multirow[t]{2}{*}{ EcoRI-AC/MspI-GT } & AFLP-10-1 ${ }^{\mathrm{b}}$ & PG1 \\
\hline & AFLP-10-2 ${ }^{\mathrm{b}}$ & PG2 \\
\hline EcoRI-TC/MspI-TA & AFLP-11-1 ${ }^{\mathrm{b}}$ & PG2 \\
\hline
\end{tabular}

a PG1: isolates causing mild form of Verticillium wilt; PG2: isolates causing lethal form of Verticillium wilt.

b Successfully cloned AFLP fragments. mg/liter. The size of the cloned AFLP fragments was verified by PCR analysis using the corresponding AFLP primers or universal primers $\mathrm{T} 3$ and $\mathrm{T} 7$. The recombinant plasmids were extracted by using a NucleoSpin Plasmid Kit (Macherey-Nagel GmbH \& Co., Duren, Germany) and fragments were sequenced by the dideoxy chain terminator method using a Thermo Sequenase Cy5 Dye Terminator Kit and an automated sequencer ALFexpresII (Amersham Biosciences, Freiburg, Germany). Sequences were assembled by an ALFwin Sequence Analyzer 2.10 and have been deposited in the GenBank of the National Center for Biotechnology Information (NCBI) under accession numbers AY518585, AY534125, AY534126, AY534127, AY534128, AY534129, AY534130, AY534131, AY534132, AY534133, AY534134, AY534135, AY534136, AY534137, AY534138, and AY534139. Sequence homologies were analyzed with the BLASTN and BLASTX programs (1) at the NCBI network service.

Design of SCAR primers and PCR. Primers for candidate SCAR markers were designed using Primer 3 (25) and NetPrimer (Premier Biosoft International, Palo Alto, CA) software to test their specificity. For each cloned AFLP fragment, two pairs of primers were made from each sequence. The first pair, designated "external," was designed as described by $\mathrm{Xu}$ et al. (33), and included recognition sites for EcoRI/MspI restriction enzymes, two selective base pairs, and the internal sequences from both ends of the AFLP fragment to a common length of 18 to $23 \mathrm{bp}$. The second primer pair, "internal," was designed from the internal part of the sequences. For both sets of primers, care was taken to avoid secondary structures, primer dimer generation, and cross hybridization. The primers were synthesized by MWG Biotech (Ebersberg, Germany). 
markers generated by all primer combinations used (Table 2), 11 were reamplified successfully, purified by silica suspension, and cloned into plasmid vectors. The resulting recombinant clones were screened prior to sequencing for the presence of a band similar in size to the cloned AFLP fragment. Four colonies were selected and sequenced for each AFLP marker. All sequences of 11 AFLP markers showed the presence of the initial AFLP primers and 8 AFLP markers revealed a single sequence. In the case of the AFLP-3, AFLP-4, and AFLP-10-2 markers, two to four different sequences were obtained for each marker, within a size difference range of 0 to $2 \mathrm{bp}$. This indicated contamination by adjacent bands during polyacrylamide gel isolation of AFLP markers (33) or the presence of different sequences in the same band as a consequence of the AFLP methodology (30). Sequences were analyzed for sequence homology in GenBank, and the AFLP-11 V. albo-atrum PG2 hop pathotype-specific marker showed high homology (90\% identity over a length of $101 \mathrm{bp}$ ) with a DNA fragment (NCBI accession no. AB095266) isolated from $V$. dahliae tomato pathotype and tomato or pepperpathotype (race 1) (T. Usami and Y. Amemiya, unpublished).

SCAR primer design and amplification specificity. Based on sequence data from cloned AFLP markers, candidate SCAR primers were designed to detect $V$. albo-atrum isolates belonging to hop pathotypes PG1 or PG2. To retain primer specificity, two pairs of primers, external and internal, were designed from each sequence. In summary, 16 sequences were obtained from 11 AFLP cloned fragments, and 32 primer pairs were designed. Genomic DNA from four isolates each of $V$. albo-atrum PG1 (KresCer, CasA, Zup, and Rec) and PG2 (Tr99, Vran, Ciz, and Drc) hop pathotypes were used as template DNA for PCR optimization of the primer annealing temperature (Table 3) and initial screening for primer amplification specificity.

Of the 22 candidate SCAR primer pairs for the specific detection of $V$. albo-atrum PG2 hop pathotype designed, 10 primer pairs originating from AFLP-5-1, AFLP-91, AFLP-9-2, AFLP-10-2, and AFLP-11 amplified a single band of predicted size only in isolates of the PG2 pathotype (Table 3). Eight primer pairs from four AFLP4 sequences, two primer pairs from the AFLP-5-2 marker, and two primer pairs from one AFLP-10-2 sequence showed no amplification in isolates of both pathotypes.

The amplification specificity of 10 candidate SCAR primer pairs for the detection of $V$. albo-atrum PG1 hop pathotype re- vealed successful PG1-specific amplification with six primer pairs derived from AFLP-1, AFLP-2, and AFLP-10-1 markers (Table 3). Four primer pairs originating from two AFLP-3 sequences showed amplification only with plasmid DNA transformed by the corresponding AFLP fragment.

The developed pathotype-specific SCAR markers from the initial screening were tested further on a broad range of Verticillium isolates of different species and from different hop-production regions, host plants, geographical locations, and some other soil fungi (Table 1). The results of amplification specificity tests of all developed SCAR markers are presented in Table 1.

Within PG2-specific SCAR markers, S9-1EXT and S-9-1INT markers (Table 3), which were developed from a sequence of the AFLP-9-1 marker, yielded 198- and 248-bp fragments, respectively (Fig. 1), only in the PG2 hop pathotype and lethal $V$. albo-atrum hop isolates from Slovenia. All possible combinations of primers from these two SCAR markers gave the same detection results.

SCAR marker S-9-2INT also showed high specificity, amplifying a 163-bp fragment in the PG2 and lethal Slovene hop isolates, but also in highly virulent tomato isolates from England (Aro/140; Aro/067)

Table 3. Length, nucleotide sequences, and annealing temperatures $\left(T_{a}\right)$ of sequence-characterized amplified region (SCAR) markers derived from amplified fragment length polymorphism (AFLP) markers

\begin{tabular}{|c|c|c|c|c|c|}
\hline AFLP marker & Specific for ${ }^{a}$ & SCAR marker designation ${ }^{b}$ & SCAR primer designation and sequence (5-3) & Size of product & $\mathbf{T}_{\mathbf{a}}\left({ }^{\circ} \mathbf{C}\right)$ \\
\hline \multirow[t]{3}{*}{ AFLP-1 } & PG1 & S-1EXT S-1INT & 1E-For ATTCGAGGCTCCGAGCATCC & $241 \mathrm{bp}$ & 59 \\
\hline & & & 1I-For CGAGCATCCGATGACACAG & $175 \mathrm{bp}$ & 60 \\
\hline & & & 1I-Rev AAGAGATCAATAGTCGTTTGCC & & \\
\hline \multirow[t]{4}{*}{ AFLP-2 } & PG1 & S-2EXT S-2INT & 2E-For ATTCGACGGACTATTCGTAAC & $180 \mathrm{bp}$ & 60 \\
\hline & & & 2E-Rev GGTAGGTAGCACGGCACTCG & & \\
\hline & & & 2I-For CGGACTATTCGTAACGGTCGG & $167 \mathrm{bp}$ & 60 \\
\hline & & & 2I-Rev AGCACGGCACTCGTTAGGT & & \\
\hline \multirow[t]{4}{*}{ AFLP-5-1 } & PG2 & S-5-1EXT S-5-1INT & 5-1E-For GGGTCGATACGATTCACGAA & $174 \mathrm{bp}$ & 52 \\
\hline & & & 5-1E-Rev ATTCGAGGCCAAGATACAGT & & \\
\hline & & & 5-1I-For GATTCACGAACTGGCCTTC & $157 \mathrm{bp}$ & 59 \\
\hline & & & 5-1I-Rev GCCAAGATACAGTCAAGGTAAA & & \\
\hline \multirow[t]{4}{*}{ AFLP-9-1 } & PG2 & S-9-1EXT S-9-1INT & 9-1E-For GGTAAGACTCCTTACCGATGCTG & 248 bp & 59 \\
\hline & & & 9-1E-Rev ATTCACACGCTACATATCAAACA & & \\
\hline & & & 9-1I-For CGATGCTGGATCTGACCAATTAC & 198 bp & 65 \\
\hline & & & 9-1I-Rev ATAAGGGCAGGCAAGGCAC & & \\
\hline \multirow[t]{4}{*}{ AFLP-9-2 } & PG2 & S-9-2EXT S-9-2INT & 9-2E-For ATTCACCATCAGCCTGTGC & $190 \mathrm{bp}$ & 60 \\
\hline & & & 9-2E-Rev GGTAATCCTTGACAACAATATTC & & \\
\hline & & & 9-2I-For CAGCGATGCACCTTCAGTG & $163 \mathrm{bp}$ & 60 \\
\hline & & & 9-2I-Rev TGACAACAATATTCTCGAAGCCA & & \\
\hline \multirow[t]{4}{*}{ AFLP-10-1 } & PG1 & S-10-1EXT S-10-1INT & 10-1E-For ATTCACCCACCAGAGAGGGCAT & $622 \mathrm{bp}$ & 62 \\
\hline & & & 10-1E-Rev GGGTCATTGCTGCATGACCA & & \\
\hline & & & 10-1I-For GTCAACTGAAATGGCACCTG & $341 \mathrm{bp}$ & 59 \\
\hline & & & 10-1I-Rev TTCCTGGTTCCGAAGCAAC & & \\
\hline \multirow[t]{4}{*}{ AFLP-10-2 } & PG2 & S-10-2aEXT S-10-2aINT & 10-2aE-For ATTCACGGATCCAAGGATGGCGA & $367 \mathrm{bp}$ & 60 \\
\hline & & & 10-2aE-Rev GGGTGTGTCTCTCATAGGTA & & \\
\hline & & & 10-2aI-For GCCAGATACACCAATGTCAAC & 293 bp & 60 \\
\hline & & & 10-2aI-Rev TACGTGCCAGTAGATGCTG & & \\
\hline \multirow[t]{4}{*}{ AFLP-11 } & PG2 & S-11EXT S-11INT & 11E-For ATTCTCGCCGATCGTTACTC & $216 \mathrm{bp}$ & 63 \\
\hline & & & 11E-Rev GGTACAGCAGCAGTTCCTG & & \\
\hline & & & 11I-For GCCATCGCCAAAGTACCAT & 169 bp & 63 \\
\hline & & & 11I-Rev GCCAGATCATATACCCATTGTC & & \\
\hline
\end{tabular}

${ }^{\text {a }}$ PG1: isolates causing mild form of Verticillium wilt; PG2: isolates causing lethal form of Verticillium wilt.

${ }^{\mathrm{b}}$ EXT: SCAR markers generated from the external part of the corresponding AFLP marker; INT: SCAR markers generated from the internal part of the corresponding AFLP marker. 
and in $V$. dahliae from isolate JKG3 of Acer palmatum from Holland. SCAR primers developed for PG1 isolates were less specific, showing amplification products in $V$. albo-atrum isolates from different host plants and isolates of $V$. dahliae in addition to PG1 hop pathotypes (Table 1).

Multiplex PCR by SCAR primers. To develop a more specific test for the diagnosis of $V$. albo-atrum hop PG1 and PG2 pathotypes, multiplex PCR reactions were performed using three pairs of SCAR and 9-1E-Rev/9-1I-For (Table 3). The last primer pair was used as a combination of primers from two SCAR markers, S-91EXT and S-9-1INT, in order to achieve a uniform annealing temperature of $60^{\circ} \mathrm{C}$ for all primers. The multiplex reaction was optimized by adjusting the amount of of $\mathrm{MgCl}_{2}$. The amplified PCR products corresponded to the SCAR markers; therefore, the specificity of the primers was not affected by the multiplex reaction. The first two primer pairs from the multiplex reaction amplified a new fragment of $233 \mathrm{bp}$ and the expected 163-bp band, respecprimers: 9-2I-For/9-2I-Rev, 1I-For/1I-Rev, primers and increasing the concentration

tively, in all lethal $V$. albo-atrum hop isolates from Slovenia. The $V$. albo-atrum PG1 isolates yielded the predicted 175-bp fragment amplified by the 1I-For/1I-Rev primer pair (Fig. 2).

PCR detection of $V$. albo-atrum PG2 pathotype in hop plants. SCAR primer pair 9-1E-Rev/9-1E-For, which was specific for the detection of the PG2 pathotype, was used for testing artificially inoculated plants of hop cvs. Wye Target, Wye Challenger, Fuggle, and Celeia. The PCR product was detectable as a faint band (Fig. 3) and the results were inconsistent. In order to improve the sensitivity of detection, a nested PCR procedure was applied by using a two-step protocol. Primers of SCAR marker S-9-1EXT were used for the first amplification step in a reduced number of PCR temperature cycles. For the second step, $1 \mu \mathrm{l}$ of 1:10 diluted solution from the first PCR was used as a template for amplification using SCAR S-91INT primers. Nested PCR using genomic DNA obtained from the xylem of plants infected by the PG2 isolate amplified the predicted 198-bp specific diagnostic S-91INT marker from all tested plants. Plants

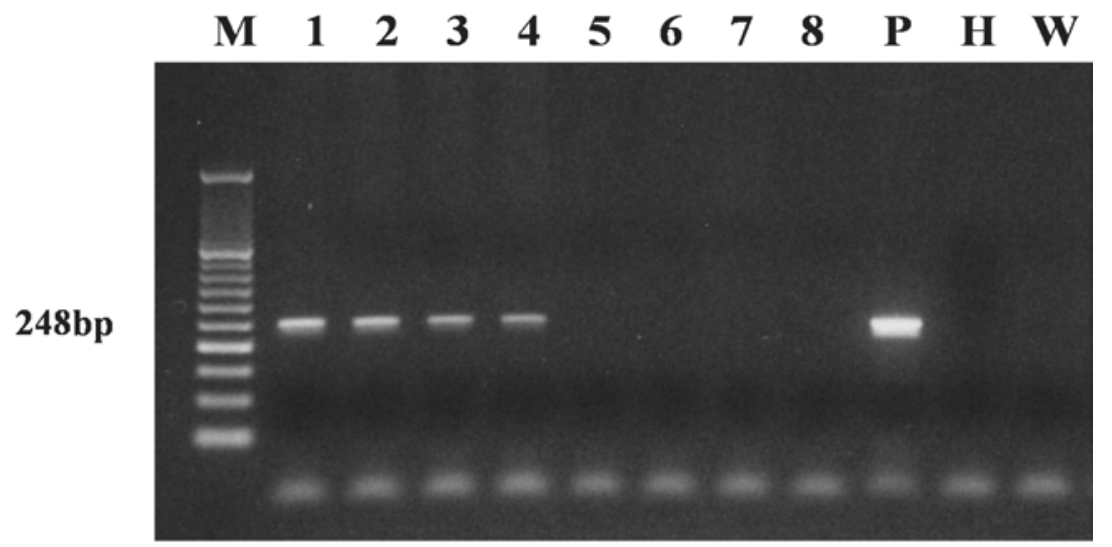

Fig. 1. Polymerase chain reaction amplification products of genomic DNA of Verticillium albo-atrum hop isolates using primers for sequence-characterized amplified region marker S-9-1EXT, which is specific for PG2 isolates. Lane M: 50-bp DNA ladder; lanes 1-4: PG2 isolates (T99, Vran, Ciz, and Drc); lanes 5-8: PG1 isolates (KresCer, CasA, Zup, and Rec); lane P: positive control (plasmid cloned AFLP-9-1 marker); lane H: hop genomic DNA; lane W: water control.

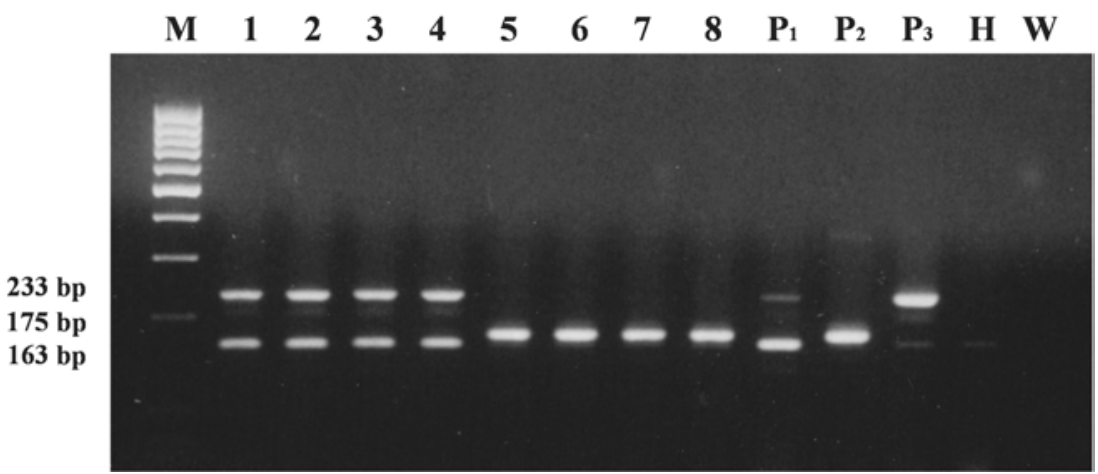

Fig. 2. Identification of Verticillium albo-atrum PG1 and PG2 hop pathotypes by multiplex polymerase chain reactions. Lane M: 100-bp DNA ladder; lanes 1-4: PG2 isolates (T99, Vran, Ciz, and Drc); lanes 5-8: PG1 isolates (KresCer, CasA, Zup, and Rec); $\mathrm{P}_{1}$ : positive control (plasmid cloned AFLP-9-2 marker); $\mathrm{P}_{2}$ : positive control (plasmid cloned AFLP-1 marker); $\mathrm{P}_{3}$ : positive control (plasmid cloned AFLP-9-1 marker); lane H: hop genomic DNA; lane W: water control. inoculated with sterile distilled water or PG1 isolate did not produce any amplification products (Fig. 3). The quality of isolated total DNA seemed to be important for the specific amplification, because DNA isolated by the CTAB protocol gave much better results than DNA isolated by the SDS protocol. The results of the nested PCR were validated by culturing plant samples on PDA, followed by microscopic identification of the fungi obtained and SCAR amplification with DNA extracted from the cultured isolates.

\section{DISCUSSION}

Since 1997, Verticillium wilt has been a serious limiting factor in hop production in Slovenia. The importance of rapid detection of hop pathotypes has been recognized in order to improve the efficiency of disease management, accelerate resistance breeding, and contribute to epidemiological studies. Various techniques have been employed to develop PCR assays for genetic identification and diagnosis of Verticillium spp.. Specific primers based on ITS rDNA sequences previously have been designed to identify and distinguish $V$. albo-atrum, $V$. dahliae, and $V$. tricorpus $(18,19,24)$. Sets of primers also are available for the detection of $V$. albo-atrum lucerne (L), nonlucerne (NL), and potato subgroups $(4,24)$.

Our previous study of Slovene $V$. alboatrum isolates by pathogenicity tests and molecular analysis revealed two hop pathotypes, PG1 and PG2, which express differences in virulence and cause either the mild or the lethal form, respectively, of Verticillium wilt (22). That study identified 17 AFLP markers linked to V. albo-atrum hop pathotype specificity. Successful conversion of AFLP fragments into SCAR markers enables the extension of their applicability to less laborious, rapid, locusspecific diversity assessment $(3,33)$. Such a conversion has been attempted for many AFLP markers, but only a few retain their sequence specificity or ability to amplify genomic DNA $(10,28)$. A possible reason for the lack of efficient conversion may lie in the nature of AFLP. The specificity may be lost when primers are generated from the internal parts of the AFLP sequences and nucleotide differences specific for AFLP primers are excluded $(28,32)$. Therefore, we designed two primer pairs for each AFLP fragment sequence, one of which was based on the internal part of the sequence, and the second (extended) which included the AFLP primer sites. In summary, from 17 polymorphic AFLP fragments, 11 were successfully cloned and 16 sequences were obtained, which served for the design of 32 candidate SCAR primer pairs. Testing of primer pairs on representative isolates of PG1 and PG2 resulted in 6 and 10 primer pairs specific for the PG1 and PG2 pathotypes, respectively. All PG2-specific primers also amplified diag- 
nostic SCAR markers in Slovene hop isolates uncharacterized by the pathogenicity test, but obtained from plants showing lethal hop wilt symptoms; such isolates were thus, considered to be the PG2 pathotype.

When the specificity of the primers derived from SCAR markers was tested on a ers from the AFLP 9-1 fragment retained their specificity for PG2. All other SCAR markers also were amplified in either $V$. albo-atrum hop isolates and $V$. dahliae isolate JKG3 or JKG10 from Holland and in some hop isolates from Slovenia, England, and Germany. SCARs specific for PG1 also were amplified, in addition to mild Slovene hop isolates, in some German and Polish hop isolates, implying similarities among those hop isolates causing mild wilt. Five PG2-specific SCARs obtained from AFLP-5-1, AFLP-9-2, and AFLP 10-2a markers also were amplified in all English isolates, except isolates 1953, 298092, and 298095, which are characterized as mild hop isolates. Furthermore, three PG2 SCARs from AFLP-5-1, AFLP-9-2, and AFLP-11 also were found in lucerne isolates (Table 1). These results suggest specific similarities among PG2, lucerne, and isolates from England, but the broad range of isolates, only SCAR prim-

degree of genetic relationship among isolates analyzed needs to be assessed by a larger number of markers.

In addition, very high sequence identity was found between the hop PG2 pathotype AFLP-11 fragment and a DNA fragment isolated from the tomato pathotype and tomato or pepper pathotype of $V$. dahliae (T. Usami and Y. Amemiya, 2002; unpublished). Such analysis may provide the means for better understanding the pathogenicity of Verticillium isolates in the future.

Identification of Slovene $V$. albo-atrum PG1 and PG2 hop pathotypes by SCAR markers was further improved by the development of multiplex PCR. Such a test increases specificity in the diagnosis of these pathotypes by means of simultaneous amplification of two specific loci for PG2 and one for PG1 (Fig. 2) and can make pathotype screening assays more reliable.

In addition to pathotype identification from fungal genomic DNA, PCR assays for the detection of pathogens in plants allow direct detection in wilted plants and quantification of the pathogen biomass in plants. Such an approach, applying different markers to the detection and quantification of plant-pathogenic Verticillium spp., already has been used in alfalfa, sun-
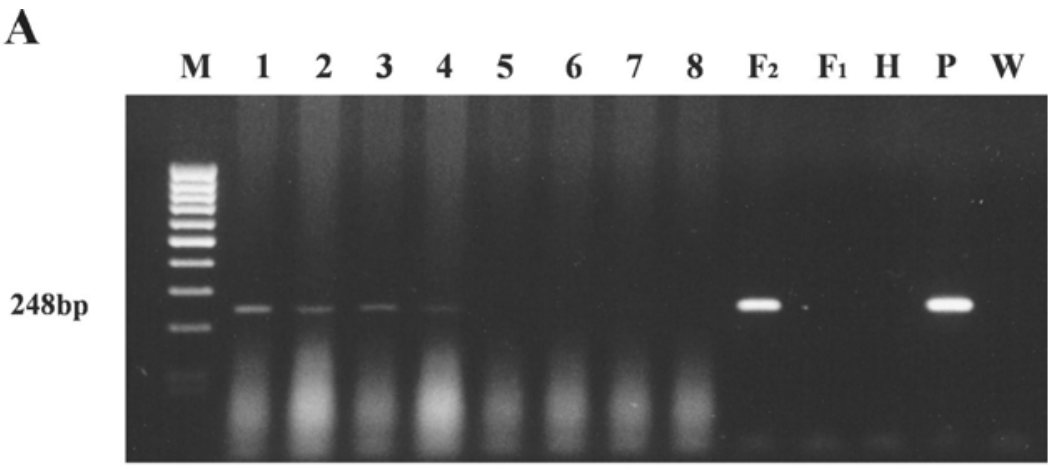

B

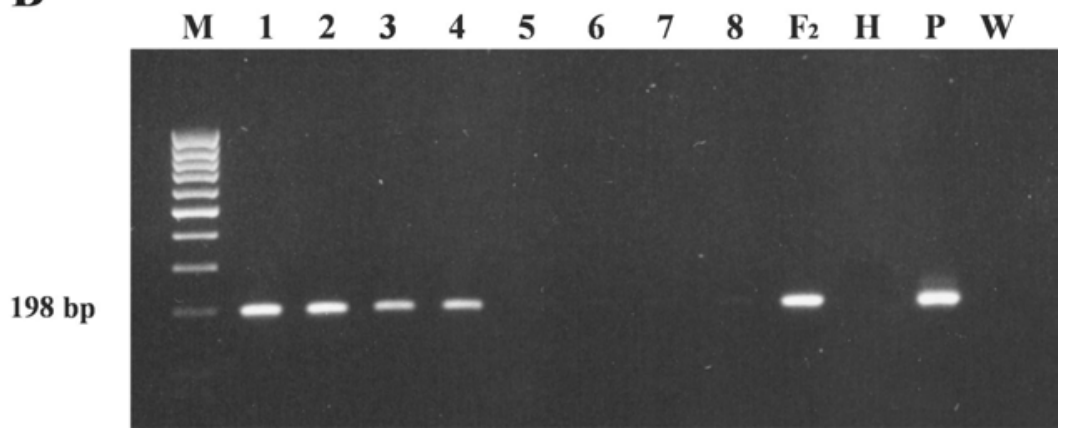

Fig. 3. Detection of Verticillium albo-atrum PG2 hop pathotype in xylem tissue of artificially infected hop cultivars. Lane M: 100-bp ladder; lanes 1 through 4: total genomic DNA of cvs. Celeia, Fuggle, Wye Challenger, and Wye Target, respectively, infected by PG2 isolate Tr99; lanes 5 through 8: the same cultivars infected by PG1 isolate KresCer; lane $\mathrm{F}_{2}$ : positive control (genomic DNA of $\operatorname{Tr} 99$ isolate); Lane $\mathrm{F}_{1}$ : negative control (genomic DNA of KresCer isolate); $\mathrm{H}$ : hop genomic DNA; P: plasmid positive control; W: water control. A, Amplification products from single polymerase chain reaction (PCR) of total genomic DNA by using primers for sequence-characterized amplified region marker S-9-1EXT. B, Nested PCR amplification products obtained with external primers S-9-1EFor/S-9-1E-Rev, followed by S-9-1I-For/S-9-1I-Rev internal primer pair obtained from amplified fragment length polymorphism 9-1 sequence. flower, tomato, potato, and olive $(6,11,12,16,18)$. In our study, SCAR primers from the AFLP-9-1 fragment were used for the detection of the V. albo-atrum PG2 hop pathotype in artificially infected hop plants of resistant cvs. Wye Target and Wye Challenger and susceptible Fuggle and Celeia. The detection of PG2 in total genomic DNA by single PCR using S-91I-For/ S-9-1I-Rev or S-9-1E-For/ S-9-1ERev primer pairs gave faint bands and inconsistent results (Fig. 3), probably due to a significantly lower concentration of fungal plant DNA and the presence of PCR plant-derived inhibitory compounds $(7,23)$. In order to increase detection sensitivity, a nested PCR was employed, in which templates first were subjected to amplification with external primers S-9-1E-For/S-9-1ERev, followed by S-9-1I-For/S-9-1I-Rev internal primer pair obtained from the AFLP-9-1 sequence. The nested PCR demonstrated consistent detection of the PG2 pathotype in all tested plants, irrespective of cultivar resistance (Fig. 3).

In conclusion, we report here on the conversion of $V$. albo-atrum PG1 or PG2 pathotype-specific AFLP markers into more diagnostically applicable SCAR markers. From 16 developed SCARs, two markers (S-9-1INT and S-9-1EXT), specific for the detection of the highly virulent PG2 hop pathotype, retain specificity under testing on a wide range of isolates from important hop-growing regions in Europe where hop wilt has appeared to date, as well as isolates from different hosts and Verticillium spp. The remaining SCAR pathotype-specific markers may be useful for the identification of $V$. albo-atrum isolates from Slovene hop-growing regions. The first hop pathotype-specific SCAR markers presented in this study are of potential importance for future diagnostic studies and for complementation in genetic analysis of Verticillium isolates.

\section{ACKNOWLEDGMENTS}

We thank D. J. Barbara, R. Cooper, G. Down, J.K. Goud, J. Robb, E. Seigner, and E. Solarska for kindly providing Verticillium isolates.

\section{LITERATURE CITED}

1. Altschul, S. F., Madden, T. L., Schaffer, A. A., Zhang, J., Zhang Z., Miller, W., and Lipman, D. J. 1997. Gapped BLAST and PSI-BLAST: a new generation of protein database search programs. Nucleic Acids Res. 25:3389-3402.

2. Boyle, J. S., and Lew, A. M. 1995. An inexpensive alternative to glassmilk for DNA purification. Trends Genet. 11(1):8.

3. Bradeen, J. M., and Simon, P. W. 1998. Conversion of an AFLP fragment linked to the carrot $\mathrm{Y}_{2}$ locus to a simple, codominant, PCRbased marker form. Theor. Appl. Genet. 97:960-967.

4. Carder, J. H., Morton, A., Tabrett, A. M., and Barbara, D. J. 1994. Detection and differentiation by PCR of subspecific groups within two Verticillium species causing vascular wilts in herbaceous hosts. Pages 91-97 in: Modern Detection Assays for Plant Pathogenic Fungi: Identification, Detection and Quantification. A Schots, F. M. Dewey, and R. Oliver, eds. CAB 
International, Wallingford, UK

5. Clarkson, J. M., and Heale, J. B. 1985. Pathogenicity and colonization studies on wild-type and auxotrophic isolates of Verticillium alboatrum from hop. Plant Pathol. 34:119-128.

6. Dan, H., Ali-Khan, S. T., and Robb, J. 2001. Use of quantitative PCR diagnostics to identify tolerance and resistance to Verticillium dahliae in potato. Plant Dis. 7:700-705.

7. Demeke, T., and Adams, R. P. 1992. The effect of plant polysaccharides and buffer additives on PCR. BioTechniques 12:332-333.

8. Dolinar, M. 1975. Hop wilt (Verticillium alboatrum and Verticillium dahliae). Report for 1975. Zalec Institute for Hop Research and Brewing, Žalec, Slovenia

9. Engelhard, A. W. 1957. Host index of Verticillium albo-atrum (including Verticillium dahliae Kleb.). Plant Dis. Rep. Suppl. 244:23-49.

10. Evans, K. M., and James, C. M. 2003. Identification of SCAR markers linked to $\mathrm{Pl}$-w mildew resistance in apple. Theor. Appl. Genet. 106:1178-1183.

11. Heinz, R. A., and Platt, H. W. 2000. A competitive PCR-based assay to quantify Verticillium tricorpus propagules in soil. Can. J. Plant Pathol. 22:122-130.

12. Hu, X., Nazar, R. N., and Robb, J. 1993. Quantification of Verticillium biomass in wilt disease development. Physiol. Mol. Plant Pathol. 42:23-36.

13. Isaac, I., and Keyworth, W. G. 1948. Verticillium wilt of the hop (Humulus lupulus). A study of the pathogenicity of isolates from fluctuating and from progressive outbreaks. Ann. Appl. Biol. 35:243-249.

14. Kump, B., and Javormik, B. 1996. Evaluation of genetic variability among common buckwheat (Fagopyrum esculentum) populations by RAPD markers. Plant Sci. 114:149-159.

15. Lee, S. B., and Taylor, J. W. 1990. Isolation of DNA from fungal mycelia and single spores.
Pages 282-287 in: PCR Protocols. A Guide to Methods and Applications. M. A. Innis, D. H. Gelfand, J. J. Sninsky, and T. J. White, eds. Academic Press, San Diego, CA.

16. Mercado-Blanco, J., Rodríguez-Jurado, D., Péres-Artés, E., and Jiménez-Díaz, R. M. 2002. Detection of the defoliating pathotype of Verticillium dahliae in infected olive plants by nested PCR. Eur. J. Plant Pathol. 108:1-13.

17. Morton, A., Carder, J. H., and Barbara, D. J. 1995. Sequences of the internal transcribed spacers of the ribosomal RNA genes and relationships between isolates of Verticillium alboatrum and V. dahliae. Plant Pathol. 44:183-190.

18. Moukhamedov, R., Hu, X., Nazar, R. N., and Robb, J. 1994. Use of polymerase chain reaction-amplified ribosomal intergenic sequences for the diagnosis of Verticillium tricorpus. Phytopathology 84:256-259.

19. Nazar, R. N., Hu, X., Schmidt, J., Culham, D., and Robb, J. 1991. Potential use of PCRamplified detection and differentiation of Verticillium wilt pathogens. Physiol. Mol. Plant Pathol. 39:1-11.

20. Paran, I., and Michelmore, R. W. 1993. Development of reliable PCR-based markers linked to downy mildew resistance genes in lettuce. Theor. Appl. Genet. 85:985-993.

21. Pegg, G. F. 1984. The impact of Verticillium diseases in agriculture. Phytopathol. Mediterr. 23:176-192.

22. Radišek, S., Jakše, J., Simon i, A., and Javornik, B. 2003. Characterization of Verticillium albo-atrum field isolates using pathogenicity data and AFLP analysis. Plant Dis. 87:633-638.

23. Robb, J., Hu, X., Platt, H., and Nazar, R. 1994. PCR assay for the detection and quantification of Verticillium species in potato. Pages 83-90 in: Modern Detection Assays for Plant Pathogenic Fungi: Identification, Detection and Quantification. A. Schots, F. M. Dewey, and R. Oliver, eds.
CAB International, Wallingford, UK

24. Robb, J., Moukhamedov, R., Hu, X., Platt, H., and Nazar, R. 1993. Putative subgroups of Verticillium albo-atrum distinguishable by PCRbased assay. Physiol. Mol. Plant Pathol 43:423-436.

25. Rozen, S., and Skaletsky, H. J. 2000. Primer3 on the WWW for general users and biologist programmers. Pages 365-386 in: Bioinformatics Methods and Protocols: Methods in Molecular Biology. S. Krawetz and S. Misener, eds. Humana Press, Totowa.

26. Sewell, G. W. F., and Wilson, J. F., 1974. Hop wilt, soil temperature and nitrogen. East Malling Res. Stn. Annu. Rep. 1973:203-204.

27. Sewell, G. W. F., and Wilson, J. F. 1984. The nature and distribution of Verticillium alboatrum strains highly pathogenic to the hop. Plant Pathol. 33:39-51.

28. Shan, X., Blake, T. K., and Talbert, L. E. 1999. Conversion of AFLP markers to sequencespecific PCR markers in barley and wheat Theor. Appl. Genet. 98:1072-1078.

29. Talboys, P. W. 1972. Resistance to vascular wilt fungi. Proc. R. Soc. (Lond.) 181:319-333.

30. Vos, P., Hogers, R., Bleeker, M., Reijans, M. van de Lee T., Hornes, M., Frijters, A., Pot, J. Peleman, J., Kuiper, M., and Zabeau, M. 1995. AFLP: a new technique for DNA fingerprinting. Nucleic Acids Res. 23:4407-4414.

31. Weising, K., Nybom, H., Wolff, K., and Meyer, W. 1995. Fingerprinting in Plants and Fungi. CRC Press, Inc., London.

32. Weng, C., Kubisiak, T. L., and Stine, M. 1998. SCAR markers in longleaf pine $\times$ slash pine $F_{1}$ family. For. Genet. 5:239-247.

33. Xu, M., Huaracha, E., and Korban, S. S. 2001. Development of sequence-characterized amplified regions (SCARs) from amplified fragment length polymorphism (AFLP) markers tightly linked to the $V f$ gene in apple. Genome 44:63-70. 